\title{
ANALISIS KANDUNGAN ZAT BESI (FE) PADA BUAH KELOR (MORINGA OLEIFERA) ASAL KABUPATEN PANGKEP
}

\author{
Wa Ode Rustiah ${ }^{1)}$ \\ ${ }^{1)}$ AkademiAnalisKesehatanMuhammadiyah Makassar \\ Alamat Korespondensi: tia_devina@yahoo.com
}

\begin{abstract}
Abstrak
Zat besi ( $\mathrm{Fe}$ ) merupakan salah satu mineral yang terkandung dalam kelor. Zat besi ( $\mathrm{Fe}$ ) adalah mikromineral yang sangat penting dalam tubuh karena berfungsi dalam pembentukan sel darah merah. Zat besi $(\mathrm{Fe})$ dalam pembentukan sel darah merah yakni proses sintesis hemoglobin $(\mathrm{Hb})$ dapat pula mengaktifkan beberapa enzim salah satunya yakni enzim pembentuk antibodi. Kekurangan zat besi $(\mathrm{Fe})$ akan mengakibatkan anemia yang merupakan masalah gizi di Indonesia. Selain itu, dapat menurunkan kekebalan tubuh karena berhubungan erat dengan penurunan fungsi enzim pembentuk antibodi. tujuan dari penelitian ini adalah untuk mengetahui kadar zat besi ( $\mathrm{Fe})$ pada buah kelor. Penelitian ini adalah penelitian jenis eksperimen dengan menganalisis mineral yakni zat besi $(\mathrm{Fe}$ ) dimana digunakan sebagai suplemen dalam tubuh. Pada penelitian ini digunakan buah kelor sebagai sampel dengan tujuan untuk mengetahui kadar zat besi ( $F e$ ) pada sampel tersebut. Kandungan zat besi ( Fe) dalam sampel digunakan cara Spektrofotometer Serapan Atom (SSA). Untuk buah kelor, kadar zat besi (Fe) rata-rata pada titik A yakni 2,50 mg/lo0 gram sampel, titik B yakni 3,20 mg/100 gram sampel, titik C yakni 3,59 mg/lo0 gram sampel dan titik D yakni 4,51 mg/lo0 gram sampel.
\end{abstract}

Kata Kunci : Buah Kelor, Spektrofotometri Serapan Atom (SSA) dan Zat Besi (Fe)

\section{PENDAHULUAN}

Di daerah-daerah dingin, sayuran daun hijau sering dikelola dalam rumahrumah kaca yang memerlukan perawatan khusus. Sebaliknya di daerah tropis seperti Indonesia sayuran daun hijau mudah tumbuh di mana saja. Sayuran daun hijau dapat menambah kandungan mineral dan vitamin pada bahan makanan.

Tumbuhan pada umumnya mendapat asupan mineral-mineralnya melalui akar. Sayuran adalah salah satu tanaman yang mengandung mineral dimana mineral ini dibutuhkan sebagai suplemen dalam tubuh. Jumlah mineral yang dibutuhkan dalam tubuh hanya sedikit. Namun yang harus diperhatikan bukan jumlah mineralnya saja, melainkan juga mutu dari mineral tersebut. Mineral yang sangat dibutuhkan bagi tubuh yakni zat besi $(\mathrm{Fe})$, kalsium (Ca) dan fosfor (F).
Mineral-mineral tersebut terdapat dalam sayuran hijau.

Tanaman kelor adalah salah satu sayuran hijau yang tumbuh di daerah tropis dan subtropis. Tanaman ini tumbuh dengan baik pada tanah lempung berpasir dengan derajat keasaman netral sampai sedikit asam dan sangat toleran terhadap tanah yang kurang akan unsur hara, termasuk daerah pantai. Secara alamiah, tanaman kelor dapat tumbuh dengan baik pada daerah dengan ketinggian lebih dari $1000 \mathrm{M}$ di atas permukaan laut dan banyak pula didapati tumbuh di tebingtebing pegunungan. Akan tetapi, tanaman kelor juga tidak jarang dijumpai di daerah dataran rendah dengan curah hujan rata-rata 200-3000 $\mathrm{mm}$ per tahun dengan suhu antara 25$40^{\circ} \mathrm{C}$. Namun, tanaman kelor toleran terhadap suhu hingga $48^{\circ} \mathrm{C}$. 
Hampir semua bagian pohon kelor bisa dimanfaatkan sebagai sumber pangan. Daun kelor yang masih muda dapat dimakan. Buah kelor yang masih muda dapat direbus seperti kedelai dengan rasa seperti aspargus. Buah yang sudah agak tua juga dapat dimakan, direbus terlebih dahulu sampai lunak sehingga mudah dibuka. Daging buahnya yang berwarna putih dapat digunakan sebagai campuran sayur.

Salah satu sifat yang menguntungkan dalam membudidayakan pohon kelor yang sudah diketahui sejak lama, yaitu minimnya penggunaan pupuk dan jarang diserang hama (oleh serangga) ataupun penyakit (oleh mikroba). Sehingga biaya untuk pemupukan, pengontrolan hama dan penyakit relatif, sangat murah. Bahkan, dari pengalaman para petani kelor yang sudah lama berkecimpung, diketahui bahwa pemupukan yang baik adalah berasal dari pupuk organik, khususnya berasal dari kacang-kacangan (misal kacang hijau, kacang kedelai ataupun kacang panjang) yang ditanamkan sekitar pohon kelor.

Beberapa identifikasi manfaat kelor terutama pada daunnya memang menakjubkan. Diketahui, bahwa kelor sebagai suplemen herbal untuk kesehatan. Kelor merupakan tanaman berkhasiat yang dapat menyembuhkan berbagai jenis penyakit, dari infeksi sampai kanker, dari penyakit parasit sampai gula darah. Buah kelor mempunyai aktivitas perlindungan yang efektif pada hati. Buah kelor muda yang dimakan mentah dapat menurunkan panas, mencegah gangguan organ hati dan limpa. Kandungan serat dan proteinnya yang tinggi sangat bermanfaat untuk menanggulangi kekurangan gizi dan diare. Dari penelitian menyebutkan bahwa ekstrak biji kelor $100 \mu \mathrm{g} / \mathrm{ml}$ memberikan pengaruh yang penting pada aktivitas antitumor.

Zat besi $(\mathrm{Fe})$ merupakan salah satu mineral yang terkandung dalam kelor. Zat besi $(\mathrm{Fe})$ adalah mikromineral yang sangat penting dalam tubuh karena berfungsi dalam pembentukan sel darah merah. Zat besi $(\mathrm{Fe})$ dalam pembentukan sel darah merah yakni proses sintesis hemoglobin $(\mathrm{Hb})$ dan dapat pula mengaktifkan beberapa enzim salah satunya yakni enzim pembentuk antibodi. Kekurangan zat besi (Fe) akan mengakibatkan anemia yang merupakan masalah gizi di Indonesia. Selain itu, dapat menurunkan kekebalan tubuh karena berhubungan erat dengan penurunan fungsi enzim pembentuk antibodi.

Menurut Untung Suwahyono, daun kelor mempunyai kandungan zat besi $(\mathrm{Fe})$ yang tinggi yakni dalam 100 gram daun kelor mengandung $7 \mathrm{mg}$ zat besi (Fe). Hasil penelitian pula menunjukkan bahwa asupan rata-rata zat besi $(\mathrm{Fe})$ sebesar 3,72 $\mathrm{mg}$ dimana 0,6 $\mathrm{mg}(16 \%)$ adalah heme dan sisanya (84\%) adalah non heme. Pemasok zat besi $(\mathrm{Fe})$ terbanyak dari golongan pangan hewani adalah ikan $(10,4 \%)$ dan dari golongan sayuran adalah daun kelor $(9,9 \%)$.

Tanaman kelor menjadi sumber mineral dan vitamin yang baik. Kandungan unsur yang bermanfaat pada pohon kelor berbeda-beda untuk masing-masing tempat akibat pengaruh agroklimat dan faktor tanah. Kandungan kadar bahan organik dan mineral dalam tanah pada suatu daerah dengan daerah lain berbeda, tergantung dari derajat keasaman $(\mathrm{pH})$, ketinggian tempat dan warna tanah.

Penelitian ini bertujuan untuk mengetahui kadar zat besi (Fe) pada buah kelor (Moringa oleifera) asal kabupaten Pangkep.

\section{METODE PENELITIAN}

\section{Alat dan Bahan}

Alat yang digunakan pada penelitian ini adalah cawan penguap, oven, pisau, neraca analitik, oven, tanur listrik, labu takar, spektrofotometer, pipet,

Bahan yang digunakan adalah buah kelor, aquabides, asam nitrat $\left(\mathrm{HNO}_{3}\right)$, asam klorida $(\mathrm{HCl})$, dan besi (Fe) 1000 ppm.

Prosedur 


\section{Perlakuan pendahuluan}

Objek yang akan dianalisis terlebih dahulu diberi perlakuan pendahuluan yakni buah kelor dipisahkan dari kulitnya yakni diambil daging buahnya lalu dipotong kecilkecil.

\section{Analisis kadar air}

Objek yang akan dianalisis yaitu buah kelor ditimbang dengan teliti sebanyak \pm 30 gram pada cawan dan diovenkan pada suhu $\pm 105^{\circ} \mathrm{C}$ selama 3 jam kemudian ditimbang hingga bobot konstan

\section{Preparasi sampel}

Sebanyak 2 gram sampel kering untuk buah kelor ditimbang dengan teliti dalam cawan penguap dan didestruksi pada tanur listrik dengan suhu $5000{ }^{\circ} \mathrm{C}$ selama 2 jam kemudian didinginkan pada suhu kamar.

Abu yang dihasilkan ditambah dengan aquabides sebanyak 10 tetes dan asam nitrat $\left(\mathrm{HNO}_{3}\right)$ pekat : Aquabides (1:1) sebanyak $3 \mathrm{~mL}$. Kelebihan asam nitrat $\left(\mathrm{HNO}_{3}\right)$ diuapkan pada lemari asam.

Cawan penguap yang berisi sampel dimasukkan dalam tanur listrik dan diabukan selama 1 jam pada suhu 5000C.

Abu didinginkan dan ditambah dengan $5 \mathrm{~mL}$ asam klorida $(\mathrm{HCl})$ pekat : aquabides (1:1), kemudian disaring. Filtrat dipindahkan dalam labu takar 25 $\mathrm{mL}$ dan cawan dibilas dengan aquabides sebanyak 3 kali kemudian diimpitkan hingga tanda batas.

Setelah itu diukur serapannya dengan Spektrofotometer Serapan Atom (SSA) dengan menggunakan lampu katoda besi $(\mathrm{Fe})$.

\section{Pembuatan Larutan Baku Kerja}

Larutan Induk Besi (Fe) 1000 ppm dipipet sebanyak $10 \mathrm{~mL}$ dan diimpitkan dengan aquabides pada labu takar $100 \mathrm{~mL}$ dengan konsentrasi larutan 100 ppm. 50

Larutan baku kerja 100 ppm dipipet sebanyak $2,5 \mathrm{~mL}, 5 \mathrm{~mL}, 7,5 \mathrm{~mL}$ dan $10 \mathrm{~mL}$ dan diimpitkan dengan aquabides dalam labu takar $50 \mathrm{~mL}$ hingga tanda batas. Larutan tersebut berturut-turut $5 \mathrm{ppm}, 10 \mathrm{ppm}, 15 \mathrm{ppm}$ dan $20 \mathrm{ppm}$.

Masing-masing larutan standar (5 ppm, 10 ppm, 15 ppm dan 20 ppm) ditentukan absorbannya dengan Spektrofotometer Serapan Atom (SSA)

\section{Pembuatan kurva baku besi (Fe)}

Kurva baku Besi (Fe) dibuat dengan cara memplotkan absorbansi larutan standar terhadap konsentrasi larutan standar.

\section{HASIL DAN PEMBAHASAN}

Pada penelitian ini dilakukan Preparasi sampel di Laboratorium Kimia Balai Besar Industri dan Perkebunan Makassar dan pemeriksaan kadar zat besi (Fe) pada buah kelor (Moringa oleifera) asal Kabupaten Pangkep di Laboratorium Kesehatan Makassar.

Telah dilakukan percobaan untuk menentukan kadar air pada sampel buah kelor asal kab. Pangkep. Adapun hasil analisis kadar air dapat dilihat pada tabel 1.

Tabel 1.Kadar air pada buah kelor dan daun kelor

\begin{tabular}{ccc}
\hline & Sampel & $\begin{array}{l}\text { Kadar } \\
(\%) \\
\text { Buah Kelor }\end{array}$ \\
\hline pada \\
Titik A & Ulangan I & 86,73 \\
& Ulangan II & 85,68 \\
Titik B & Ulangan I & 86,22 \\
Titik C & Ulangan II & 85,53 \\
& Ulangan I & 86,24 \\
Titik D & Ulangan II & 86,65 \\
& Ulangan I & 85,59 \\
& Ulangan II & 85,70 \\
\hline
\end{tabular}

Keterangan :

Titik A = Bagian utara desa Bonto

puca

Titik B = Bagian timur desa Bonto

puca

Titik C = Bagian selatan desa Bonto

puca

Titik $\mathrm{D}=$ Bagian barat desa Bonto puca

Dari hasil pengukuran serapan larutan sampel buah kelor untuk analisis zat besi (Fe) dengan Spektrofometer Serapan Atom (SSA) dan hasil analisis data diperoleh konsentrasi zat besi $(\mathrm{Fe})$ pada buah kelor yang tumbuh di desa Bonto puca, kab. Pangkep dapat dilihat pada tabel 2. 
Tabel 2.Kadar Zat Besi (Fe) pada

\begin{tabular}{clcc}
\hline Sampel & $\begin{array}{l}\text { Kadar Zat } \\
\text { Besi } \\
\text { Buah } \\
\text { Kelor } \\
(\mathbf{m g} / \mathbf{1 0 0} \\
\mathbf{g r})\end{array}$ & $\begin{array}{c}\text { Rata-rata } \\
\mathbf{K a d a r} \mathbf{Z a t} \\
\text { Besi (Fe) } \\
\mathbf{B u a h} \\
\mathbf{K e l o r} \\
(\mathbf{m g} / \mathbf{1 0 0} \\
\mathbf{g r})\end{array}$ \\
\hline Titik & Ulangan I & 2,71 & 2,50 \\
A & Ulangan II & 2,29 & \\
Titik & Ulangan I & 2,45 & 3,2 \\
B & Ulangan II & 3,95 & \\
Titik & Ulangan I & 4,41 & 3,59 \\
C & Ulangan II & 2,77 & \\
Titik & Ulangan I & 4,36 & 4,51 \\
D & Ulangan II & 4,46 & \\
\hline
\end{tabular}

Dalam penelitian ini digunakan

buah kelor sebagai sampel yang akan dianalisis. Sebagai langkah awal pada penelitian ini yaitu pengeringan sampel untuk menghilangkan kadar air. Hal ini dimaksudkan untuk mengetahui bobot kering sampel. Kapasitas air yang tinggi pada bahan makanan dapat mempengaruhi hasil analisis. Air dalam bahan makanan terdapat dalam berbagai bentuk yakni air bebas, air yang terikat secara lemah dan air dalam keadaan terikat kuat membentuk hidrat. Air yang terdapat dalam bentuk bebas dapat membantu terjadinya proses kerusakan bahan makanan, misalnya proses mikrobiologis, kimiawi, ensimatik, bahkan oleh aktivitas serangga perusak.

Kandungan air dalam bahan makanan mempengaruhi daya tahan makanan terhadap serangga mikroba yang dinyatakan dengan aw (water activity) yakni jumlah air bebas yang dapat digunakan oleh mikroorganisme untuk pertumbuhannya.

Pada penelitian ini, kadar air pada buah kelor lebih tinggi dibanding kadar air pada daun kelor dan ini dapat dilihat pada tabel 3. Hal tersebut dikarenakan pada buah terdapat hormon-hormon pematangan buah yakni griberelin, cytokinin, auksin dan etilen dimana hormon-hormon tersebut dapat bekerja jika larut dalam air. Selain itu, secara fisik buah kelor berbentuk sel gabus dimana dengan bentuk ini dapat menampung air lebih banyak.

Perlakuan buah kelor dan daun kelor pada penelitian ini yakni sampel
Buah

Kelor

dalam keadaan kering didestruksi dengan tujuan untuk mengoksidasi senyawa organik maupun anorganik dengan bantuan campuran asam nitrat $\left(\mathrm{HNO}_{3}\right)$ yang bertindak sebagai asam pengoksidasi kuat. Oksida-oksida organik yang dihasilkan berupa karbondioksida $\left(\mathrm{CO}_{2}\right)$ dan air $\left(\mathrm{H}_{2} \mathrm{O}\right)$, sedangkan oksida-oksida anorganik diasumsikan berupa besi oksida $(\mathrm{FeO})$ yang diberi perlakuan sehingga memperoleh suatu atom besi $(\mathrm{Fe})$ yang diukur absorbannya dengan menggunakan alat Spektrofotometer Serapan Atom (SSA). Adapun reaksi yang terjadi yakni :

$\begin{array}{ll}\mathrm{H}_{2} \mathrm{O} & \mathrm{Fe}\left(\mathrm{NO}_{3}\right)_{2} \cdot \mathrm{H}_{2} \mathrm{O} \rightarrow \mathrm{Fe}\left(\mathrm{NO}_{3}\right)_{2}+ \\ & \mathrm{Fe}\left(\mathrm{NO}_{3}\right)_{2} \rightarrow \mathrm{FeO}+\mathrm{NO}+2 \mathrm{O}_{2} \\ & \mathrm{FeO} \rightarrow \mathrm{Fe}+\mathrm{O} \\ & \text { Dari hasil penelitian analisis }\end{array}$ kuantitatif buah kelor, dapat dilihat bahwa dari tiap-tiap titik pengambilan sampel menunjukkan adanya perbedaan kadar zat besi $(\mathrm{Fe})$. Hal tersebut disebabkan oleh beberapa faktor salah satunya yakni karena perbedaan daerah tempat tumbuh tanaman dimana setiap daerah memiliki kandungan unsur hara yang berbeda pula. Bagian mineral dari tanah dibentuk dari batuan induk oleh proses-proses pelapukan fisik, kimia, dan biologi. Susunan bahan organik tanah terdiri dari sisa biomassa tanaman dari berbagai tingkat penguraian atau pembusukan. Kebanyakan hara terdapat dalam mineral dan bahan organik dimana dalam keadaan demikian tidak larut serta tidak tersedia bagi tanaman. Unsur hara tersedia melalui pelapukan mineral dan penguraian bahan organik. Pada dasarnya kadar bahan organik dan mineral dalam tanah pada suatu daerah dengan daerah lain berbeda tergantung dari tingkat keasaman, ketinggian, cuaca dan warna tanah.

Perbedaan hasil yang diperoleh ini disebabkan oleh beberapa faktor diantaranya distribusi zat besi $(\mathrm{Fe})$ dari dalam tanah menuju ke jaringan tubuh tumbuhan. Serapan zat besi $(\mathrm{Fe})$ terkait dengan kemampuan perakaran 
mereduksi ferri $\left(\mathrm{Fe}^{+3}\right)$ menjadi ferro mutlak sebelum kation ini dapat diserap akar tanaman dimana kapasitas mereduksi akar tanaman akan meningkat jika tanaman mengalami desakan zat besi $(\mathrm{Fe})$. Selain itu, faktor lain yakni cara penanganan sampel yang kurang sempurna meliputi transportasi, suhu penyimpanan yang tidak tepat atau penyimpanan yang terlalu lama. Hal-hal tersebut dapat menurunkan kandungan gizi pada sampel.

Pengaruh umur tanaman dapat dilihat dari hasil penelitian ini, menunjukkan bahwa adanya perbedaan penyerapan mineral tanaman yang berumur lebih tua dengan tanaman berumur lebih muda yakni tanaman yang lebih muda berkonsentrasi untuk pertumbuhannya yakni meninggikan batangnya dan lebih memperkuat perakarannya sedangkan tanaman yang berumur lebih tua berkonsentrasi pada penyerapan mineral dimana dengan sistem perakaran yang sudah besar dapat menyerap mineral dan zat organik lebih banyak yang dibutuhkan oleh tubuh tumbuhan pada proses metabolismenya. Kebanyakan proses penyerapan air dan mineral terjadi di dekat ujung akar yaitu dimana epidermis permeable terhadap air dan terdapat rambut akar. Rambut akar yaitu penjuluran dan pemanjangan sel-sel epidermis akar. Partikel-partikel tanah yang umumnya dilapisi dengan air dan mineral yang terlarut melekat erat pada rambut akar tersebut.

\section{KESIMPULAN}

Berdasarkan hasil penelitian yang telah dilakukan, maka dapat disimpulkan bahwa :

1. Adanya variasi kadar zat besi $(\mathrm{Fe})$ pada buah kelor disetiap titik pengambilan sampel menunjukkan bahwa terdapat pula variasi kandungan mineral dalam tanah.

2. Pada buah kelor, memiliki kadar air yang tinggi. Hal ini disebabkan pada buah terdapat kapasitas air yang lebih banyak untuk melarutkan hormon pematangan buah.

\section{SARAN}

$\left(\mathrm{Fe}^{+2}\right)$ dan pereduksian besi $(\mathrm{Fe})$ ini Adapun saran-saran yang dapat disampaikan oleh peneliti untuk kelanjutan penelitian ini yakni:

1. Bagi peneliti lain diharapkan untuk dapat menawarkan produk zat besi (Fe) berupa food supplement yang bersumber dari tanaman kelor mengingat kadar zat besi $(\mathrm{Fe})$ dari tanaman ini cukup tinggi dan dapat toleran terhadap berbagai jenis tanah.

2. Pada penelitian selanjutnya, diharapkan pula untuk membandingkan kadar zat besi $(\mathrm{Fe})$ kelor dengan kadar zat besi $(\mathrm{Fe})$ pada sayuran lain

\section{DAFTAR PUSTAKA}

Achmad, Rukaesih. Kimia Lingkungan. Yogyakarta : CV. Andi.

Darmono. Logam Dalam Sistem Biologi Makhluk Hidup. Jakarta: UI-Pres.

Departemen Agama RI. Al-Quran dan Terjemahnya. Jakarta: Mujamma' Al Malik Fahd Li Thiba' At Al Mush-haf Asy Syarif.

Dewi, S.I. 2009. Kandungan Mineral Padi Varietas Unggul dan Kaitannya dengan Kesehatan. Available from: www.puslittan.bogor.net/index.

Hendayana, S. 1990. Kimia Analitik Instrumen. Bandung: FMIPA IKIP Bandung.

Kharistya. 2006. Teknologi Tepat Guna Biji Kelor. Available from: http://kharistya.wordpress.com/20 06/11/09/teknologi-tepat-gunapenjernihan-air-dengan-biji-kelormoringa-oleifera/

Ismail. 2006. Fisiologi Tumbuhan. Makassar: Universitas Negeri Makassar.

Ismono. Cara-Cara Optik Dalam Analisa Kimia. Bandung: Dep.Kimia ITB, 1981.

Khopkar, S.M. 2007. Konsep Dasar Kimia Analitik. Jakarta: UI-Press.

Muchtadi, D. Pengantar Ilmu Gizi. Bandung: CV Alfabeta.

Noor, A. 2002. Kimia Analisis Unsur Runut Edisi kedua. Makassar: Yayasan Mitra Sains Indonesia. 
Oomen. 1984. Si Hijau Yang Cantik.

Poerwowidodo. 1992. Telaah

Jakarta: $\quad$ PT $\quad$ Gramedia.

Kesuburan Tanah. Bandung:

Angkasa.

Ramli. 2008. Analisis Kadar Kalsium (Ca) dan Besi (Fe) Pada Bawang Merah yang Beredar di Pasaran Secara Spektroskopis Serapan Atom (Skripsi). Makassar: Universitas Negeri Makassar.

Rohman, Abdul dan Sumantri. 2007. Analisis Makanan. Yogyakarta: Gadja Mada University Press.

Sadikin, M. 2002. Biokimia Darah Cetakan I. Jakarta: Widya Medika.

Sudarmadji, dkk. 2007. Analisa Bahan Makanan dan Pertanian. Yogyakarta: Liberty.

Suriawira, U. 2009. Manfaat Daun Kelor. Available from: http://cuek.wordpress.com/2009/0 5/31/manfaat-daun-kelor/

Suwahyono, U. 2008. Mengupas Rahasia Tersembunyi Pohon Kelor. Yogyakarta: Lili Publisher.

Tejasari. 2005. Nilai Gizi Pangan. Jogyakarta: Graha Ilmu.

Widowati, dkk. 2008. Efek Toksik Logam Pencegahan dan Penanggulanngannya. Yogyakarta: CV. Andi Offset.

Winarno, F.G. 2004. Kimia Pangan Dan Gizi. Jakarta: PT Gramedia Pustaka Utama.

Yuliana, R. 2009. Mengatasi Zat Besi Tinggi Dalam Air. Available from:

http://advancebpp.wordpress.com.

Yuanita, L. 2005. Pengaruh $p H$ dan Lama Perebusan Kacang Panjang Terhadap Efesiensi Regenerasi $\mathrm{Hb}$ Rattus Norvegicus dan Pengikatan $\mathrm{Fe}$ Oleh Serat Pangan. Jurnal Unair Vol.21, No.2. Available from: www.journal.unair.ac.id/filerPDF /MKH-21-2-17.pdf. 